\title{
12
}

\section{Environmentally related international migration: Policy challenges}

\author{
Victoria Mence and Alex Parrinder
}

Policy deliberations on environmentally related migration ${ }^{1}$ have encountered a number of substantial challenges. The potential scale of environmentally related migration across borders both currently and in the future is unknown. Further research is required on the relationship between environmental factors and international migration to better understand what lies ahead and the implications this might have for Australia's policies to manage both regular and irregular migration. Challenges at the international, regional and national levels for policymakers involve understanding environmental impacts on human movement and the possible increase in the volume of international migration, including irregular migration, that may follow. In addition, the potential for environmental and climate change displacement to impact on states' viability (or parts thereof) and the ability of migrants to return is very difficult to quantify. From an Australian perspective, there is a perception that many of the challenges relate to the issues faced by Pacific Island nations, although there are implications for environmentally related movement in the broader Asia-Pacific region.

1 In this chapter the term 'environmentally related migration' is used to refer to the range of issues relevant to the relationship between the environment, climate change and migration. 
It is widely recognised that there have been significant problems relating to historical research on environmentally related migration including because of the contentious and politicised context in which the knowledge base has developed. One effect of this schism is a dearth of empirical research and robust evidence on key concerns and a lack of clarity around international and national normative frameworks regarding environmentally related migration. The difficulties involved in conceptualising and defining the complexities of environmentally related migration are central to the challenge of increasing the knowledge base and engaging in effective policy deliberations and the formulation of policy responses.

The purpose of this chapter is to provide background on the key issues relating to environmentally related migration, including the debate on connections between migration and environmental stress; the development of global, regional and national-level policy responses (including policy considerations relevant to Australia); and priorities for further research. The second section below summarises the literature on this topic. The third section briefly discusses some of the key challenges for policymakers. The fourth section summarises potential future policy responses, noting examples of relevant measures that have been implemented in Australia and internationally.

While highlighting the challenges for policymakers that arise from the contested body of empirical research on environmentally related migration, it is beyond the scope of this chapter to draw conclusions on the evidence on the migration impacts of environmental factors.

\section{Literature overview}

One of the most striking features of the literature on the environmentmigration nexus is that the issues have ignited intense interest and controversy across a range of academic disciplines. There is also keen interest among the public and the media, which is often characterised by heated debate. This is not surprising given that issues around migration, such as asylum seekers, refugees, forced migrants and irregular migration are all highly contested, as are the issues of environmental degradation and climate change. 
Another feature of the literature is the enormous volume of information available from a diverse research community. In addition to numerous academic papers, there is an abundant array of reports and papers by governments, international agencies and non-governmental organisations (NGOs) (Gemenne, 2011).

Current thinking and research on the environment-migration nexus is to a large extent a product of the historical controversies that have characterised the development of research over the past two decades. Dun and Gemenne provide a useful analysis of the disciplinary divide within academia that has shaped the contested nature of much of the research. Prior to the focus on the interconnections between the environment and migration, the fields of study relating to migration and the environment evolved within very different branches of learning. Research on the environment was located in the natural sciences, and migration within the domain of the humanities and social sciences. 'Just as most classical theories on migration tend[ed] to ignore the environment as a driver of migration, most theories on environmental governance ignore[d] migration flows' (Dun \& Gemenne, 2008). Both areas of research are relatively new and both have evolved in the context of growing economic, political and social tensions.

The polemic nature of the debate has its origins in the response to initial research by environmental scholars in the 1980s that linked environmental stress and migration in the context of a limited understanding of refugee and migration epistemological frameworks. From these beginnings, research and theories on environmentally related migration evolved within two distinctive clusters of disciplinary approaches. One group included authors who based their research approaches primarily from an environmental, disaster or conflict disciplinary perspective. The other group included scholars primarily from refugee and migration disciplinary backgrounds who challenged the definitional and theoretical assumptions that underpinned this research.

Until recently much of the literature relating to the environmentmigration nexus concentrated on a number of controversial themes that surfaced in the 1980s. The most prominent included:

- the way migrants, thought to be migrating in response to environmental pressures, were described and defined; 
- the strength of the evidence used to support estimates of existing examples of environmentally related migration, and the speculative nature of the predictions made about future migration flows;

- whether a direct link can be made between environmental factors and migration or more complex causalities apply.

\section{Definitions, terminology and typologies}

One of the most important and determinative debates in the literature has been about definitions and terminology. As Castles noted, poorly conceived definitions have implications beyond the research community as 'definitions are crucial in guiding policies of governments and international agencies' (Castles, 2002, p. 9).

'Environmental refugee' was a term commonly used in the context of environmentally related migration research and, in spite of some serious problems identified relating to its use, the term is still widely used. 'Environmental refugee' as a term first gained currency in the 1980s. A number of mainly environmental researchers and commentators maintained that a significant proportion of the forced migrant population were migrating because of environmental factors. Further, it was suggested that this category of forced migrants was a hidden problem and involved people who needed protection and should be referred to as 'environmental refugees' (El-Hinnawi, 1985; Jacobson, 1988).

Without further definition, linking concepts relating to the 'environment' and 'refugees' to describe a particular group of forced migrants was regarded by many scholars as conceptually misleading and legally meaningless (Kibreab, 1997; McGregor, 1993). As Zetter and others noted, the concept of 'refugee' has a clear legal meaning and historical weight anchored in the Refugee Convention, which remains confined to the criteria outlined in its original formulation (Castles, 2002; Suhrke, 1992; Zetter, 2007).

Attempting to expand the definition to define a particular category of forced migrant, a concept that in itself is still evolving, risked undermining refugee protection by inflating the numbers and thus providing states with further reasons to step away from asylum obligations (Black, 2001; Dun \& Gemenne, 2008; Kibreab, 1997). Further, the term 'environmental refugee' also invoked some inherent assumptions about environmentally related migration, including the idea that the 
environment was the principal factor driving forced migration, and that the migration was cross-border, neither of which had been verified or supported by sound empirical evidence (Castles, 2002; Findlay \& Geddes, 2011; Kibreab, 1997; McGregor, 1993).

The challenge of identifying meaningful definitions and categorisations for migrants, especially those in crisis, was central to discussions at the recent 2013 United Nations High-Level Dialogue on Migration and Development. The term 'migrants in crisis' was used in an attempt to 'straddle traditional categories and distinctions'. The aim was to capture the complexity of mixed migration populations that can include workers, as well as asylum seekers and refugees, migrating because of political, conflict related crises and/or natural disasters (Koser, 2013).

\section{Estimates and predictions}

The use of the term 'environmental refugee' in the context of forced migration received widespread attention and prompted further research in the 1990s that made some ominous predictions about future environmentally related migration flows. These predictions have had an ongoing influence in the discussion.

One of the most prominent and prolific writers on this theme was Myers (Morrissey, 2012). In 1993, while acknowledging that some of the analysis was 'speculative' and 'essentially exploratory', Myers claimed that, based on the most conservative calculations of what he called 'this refugee problem', the movement of people 'would ... be of an altogether unprecedented scale' with an estimated 150 million environmental refugees by 2050 (Myers, 2001; Myers, 1997; Myers \& Kent, 1995; Myers, 1993, p. 752). In subsequent papers this figure rose to 200 million, a figure Myers was still predicting in 2005 (Myers, 2005). Some advocacy publications went much further with one predicting up to one billion people displaced by the end of the 21st century (Christian Aid, 2007). In 1993, a report by the United Nations High Commissioner for Refugees (UNHCR) stated that it is entirely possible that the impact of environmental degradation and resource depletion on population movement may be even more important than these authors suggest' (UNHCR, 1993, p. 5). The predictions were widely accepted and were central to a body of literature that used the predictions to highlight the risks and the dangers of not acting on climate change. 
Early critical responses to the scale of migration predicted were highly sceptical of the way the figures had been calculated. Critics argued that the figures did not take account of the role of personal agency in decisions to migrate, the ability of populations to adapt to changing conditions, nor the range of other political, economic and social factors at play (Lonergan, 1998; McGregor, 1993; Surhke, 1992).

A number of authors have suggested that there has been little appetite for reassessing the validity of the high estimates and predictions because the sheer scale of the migration predicted has successfully raised the profile of climate change and its potential consequences (Black, 2001; Castles, 2011; Crisp, 1999; Morrissey, 2009). The uncritical use of Myers' figures by international organisations, advocate groups and the media has also reinforced and influenced political and public discourse on the issues (Morrissey, 2009). However, in 2008, UNHCR warned that inflated figures were not helpful, rather they 'evoked fantasies of uncontrollable waves of migration that risk stoking xenophobic reactions' (A question of climate refugees, 2011, para. 7).

Estimates are important, but need to be based on more robust and rigorous empirical evidence. Further, research needs to be location and context specific and to take account of the multiple responses going on (Leighton, 2011). 'Mapping and monitoring potential environmental "hotspots" and changing regional conditions, and tracking migration trends, offer a more fruitful and evidence-based route for policy development' (Boano, Zetter, \& Morris, 2008).

\section{Mono-causality versus multiple causality}

Until recently, one of the most contentious disagreements in the literature related to the assumption that there were direct links between environmental factors and international migration flows. In the view of some critics, predictions were often based on a simple process of subtracting current populations living in problem areas to calculate migration flows (Black, 2001).

Those critical of attempts to draw direct correlations have long argued that the causes of migration are highly complex, involving a range of political, economic and social factors that may influence responses to environmental stress. The strength of family, social, cultural and ethnic networks, the effectiveness of state responses to disasters and the level 
of poverty and wealth all appeared to influence coping strategies and migration decisions. Further, all of these variables are likely to vary over time and space (Black, 2001; Castles, 2011).

An additional level of complexity lies in the complicated variations involved in environmentally related migration, including: internal versus cross-border; short- or long-distance; temporary or permanent; rapid- or slow-onset events, that is, forced migration as a result of an environmental catastrophe or migrants who move voluntarily in the context of environmental stress and those who leave as opposed to those who stay (Bates, 2002; Hugo, 1996; Suhrke, 1993).

There has been a growing consensus in recent literature on the environment-migration nexus that multiple causality is a crucial consideration. There is a sense in more recent literature that some of the controversies that have characterised the debate are abating. 'Although the debate still goes on, the disciplinary divide is gradually being overcome: environmental scientists tend to be more cautious while migration specialists do recognise the role of the natural environment in migration dynamics. On the whole, most scholars now dismiss the apocalyptic predictions that used to influence debates' (Piguet, 2011, p. 4). Further, there is recognition in more recent literature by migration theorists that environmentally related migration is an issue that demands greater attention.

It is significant that reference is made many times in recent literature to how much is yet unknown about the interconnections between environmental factors and migration by both migration and environment researchers (Brown, 2008; Castles, 2011; Kniveton, Schmidt-Verkerk, Smith, \& Black, 2008; Koser, 1996; Martin, 2010). This is especially true in relation to 'the circumstances in which international migration may result from climate change' (Martin, 2010).

It is evident that a more considered approach is starting to inform the discourse at a national and international governance level, as reflected in the more recent global discussions on related issues. There is also a growing recognition that an interdisciplinary approach, based on robust empirical research, is essential to support practical and realistic policy development by governments in particular. An important challenge ahead is to better negotiate the narrative in the public arena. Publications by academics containing apocalyptic themes, especially in relation to security issues, continue to have influence. 


\section{Challenges for policymakers}

There is broad agreement that most environmentally related migration is expected to be internal (International Organization for Migration [IOM], 2013; McAdam, 2012; Martin, 2010; Newland, 2011). Nonetheless, discussions of the implications of environmentally related migration for Australia often focus on the possibility of international migration from Pacific Island nations, and the challenges Australia may face in addressing such flows through its current policy settings. If significant international migration flows do eventuate, Martin (2010, p. 3) has argued that 'the immigration policies of most destination countries are not conducive to receiving large numbers of environmental migrants, unless they enter through already existing admission categories'. Martin has summarised common parameters of immigration programs, highlighting that labour migration is usually based on the needs of the receiving country and that family migration is usually restricted to immediate relatives, as well as noting that admissions are sometimes based on point systems. Martin (2010) has also noted that humanitarian admissions are generally limited to people who fit the Refugee Convention definition, and that those admitted under resettlement programs are screened overseas.

In addition to migration policy, the complexities of environmentally related migration invoke a range of other policy fields, including international development, humanitarian assistance, the environment and climate change. Government agencies in these areas have particular responsibilities in relation to different stages of environmentally related migration: contributing to global climate change mitigation; supporting adaptation and resilience of affected communities to environmental events; contributing to humanitarian and disaster relief efforts; managing the movement of people across international borders; and supporting return, resettlement and reintegration following events (Martin, 2010). These responsibilities overlap, leading some commentators to argue that existing policy fields can be relied upon to address the challenges of environmentally related migration (Piguet, Pécoud, \& de Guchteneire, 2011). Warner (2010), however, has argued that institutional and policy 'silos' limit the effectiveness of existing responses, which underscores the need for strong communication and coordination between policymakers in relevant fields if more effective responses are to be developed (Appave, 2012; Boano et al., 2008; Warner, 2010). 
Approaches to adaptation (which is usually considered a matter of international development policy) and migration have been discussed in the literature in this context. It has been suggested that not only can adaptation function as a way to reduce migration, but that migration can also function as an adaptation strategy that may significantly increase the resilience of communities to environmental and climate change impacts (Hugo, 2010; Newland, 2011; Transatlantic Study Team on ClimateInduced Migration, 2010). It is also worth noting the increasing role of diasporas in enabling a range of adaptation strategies, including beyond the provision of remittances. Such connections demonstrate the potential for effective coordination between policymakers in relevant fields. In arguing that mobilisation of resources for adaptation may be contentious, White (2011) has suggested that a key challenge lies in balancing the use of reliable research to help mobilise support for adaptation and development strategies without igniting security fears.

\section{Conceptualisation and definition}

Definitions are important for policy development, as they allow rights and obligations to be identified. As Dun and Gemenne (2008) have argued, ' $[w]$ ithout a precise definition, practitioners and policymakers are not easily able to establish plans and make targeted progress' (p. 10). Many commentators have considered the challenge of defining environmentallyrelated migration to be complicated by 'the lack of good information and analysis about the circumstances in which international migration may result from climate change' (Martin, 2010, p. 2).

In the absence of a clear definition, McAdam (2012) has neatly summarised a range of considerations that responses to environmentally related migration will depend on: '(a) whether such movement is perceived as voluntary or involuntary; (b) the nature of the trigger (a rapid-onset disaster versus a slow-onset process); (c) whether international borders are crossed; (d) the extent to which there are political incentives to characterise something as linked to climate change or not; and (e) whether movement is driven or aggravated by human factors, such as discrimination' (p. 17).

A number of commentators have argued that effective policy responses need to recognise the multiple causality of migrant decision-making processes and take into account the social, economic, cultural and political factors involved (Black, 2001; Castles, 2011; Hugo, 2010; Zetter, 2010). Findlay and Geddes (2011) have emphasised the need for policymakers to 
appreciate the existing local context and to understand that 'those affected by environmental change are not simply passive populations onto which externally defined practices need to be imposed to protect them from "risk"' (p. 153). They have suggested the value of a policy approach that involves local populations as 'purposive actors' in addressing the challenges posed by the environment-migration nexus (Findlay \& Geddes, 2011).

These considerations apply in cases where migration is perceived as voluntary as well as cases where it is perceived as forced, which Hugo (2010) has described as extremes along a continuum where, in reality, different levels of force operate in different circumstances. The nature of an environmental event-whether it is regarded as a rapid-onset (e.g. tsunami, flooding) or slow-onset (e.g. desertification, 'sinking islands') process — and its impact in the particular circumstances also have implications for policy responses.

It has been suggested that 'climate change impacts' should be distinguished from other environmental factors. Climate change processes have been argued to be connected to broader issues of human vulnerability that affect populations (e.g. rapid-onset environmental disasters, conflict), acting as a 'threat multiplier' that increases the likelihood of migration (Collinson, 2010; Kirsh-Wood, Korrebord, \& Linde, 2008). Conversely, others have suggested that vulnerability can be aggravated in a very different way (e.g. reduced livelihoods, increased poverty), and that climate change processes thus act to reduce people's ability to migrate (Geddes \& Somerville, 2013). Nevertheless, Zetter has argued that 'the interrelatedness of climate change, general changes in environmental conditions and socioeconomic factors which underpin decisions to migrate' makes it difficult to develop policy responses in relation to migration that is related specifically to climate change (Zetter, 2010).

Noting the disparate array of scenarios in which environmentally related migration may occur, McAdam (2011) has argued that it is not yet clear whether a universally applicable definition of those displaced by climate change is necessary or desirable' (p. 4). 


\section{Future policy: What is possible?}

A range of policy responses to environmentally related migration have been proposed at both the international and national levels. At the international level, policy responses (proposed and/or current) include frameworks based on refugee protection, complementary protection, a new international instrument, protection of internally displaced people, and regionally based responses. Unsurprisingly, none of these has successfully overcome the fundamental difficulty of conceptualising environmentallyrelated migration in order to address the range of circumstances in which it might occur.

Notwithstanding the challenges that exist in the international arena, a number of countries have implemented domestic laws and policies regarding environmentally related migration. These measures also have limited applicability, and none would appear to effectively address migration induced by slow-onset processes. A summary of the nationallevel responses is provided below.

\section{Refugee framework}

Proposals to expand the Refugee Convention to protect people who move across borders due to environmental and climate change factors have been discussed extensively at the international level. The Office of UNHCR does not support revision of the Refugee Convention, and has argued that 'refugee' is a legal term with a settled meaning centred on persecution. People whose movement is related to environmental factors would not normally qualify as refugees, although some could fall within UNHCR's mandate (e.g. where conflict is involved, where governments persecute those affected by withholding assistance, or where statelessness is a concern). According to UNHCR, the terms 'environmental refugee' and 'climate refugee' have no basis in international law and their use could confuse environmental factors with persecution, potentially undermining refugee protection standards (UNHCR, 2009).

Other critiques of this approach have noted that refugee protection applies only to people who have already crossed international borders, while most environmentally related migration is expected to be internal. The term 'refugee' has also been seen to imply forced movement (Zetter, 2010), which may apply in particular circumstances of rapid-onset environmental 
disasters, but becomes much less clear in cases where people are considered to be migrating voluntarily in anticipation of slow-onset environmental or climate change impacts (Hugo, 2010).

\section{Complementary protection framework}

It has been suggested that nonrefoulement obligations under international human rights law might provide another avenue for protecting those affected by environmental and climate change factors (McAdam, 2012; European Commission [EC], 2013). This is envisaged primarily under the right to life (where relevant issues may be standard of living, means of subsistence, survival and protection of life, which could be affected by environmental factors) and the prohibition against torture and cruel, inhuman and degrading treatment or punishment (where return to socioeconomic deprivation, including that caused by humanitarian disasters, could constitute inhuman and degrading treatment) (United Nations General Assembly [UNGA], 1966). However, it is unclear in practice whether such claims can be relied upon: the harm faced must be found to be sufficiently severe and 'imminent'. As with refugee protection, this may imply forced movement, while migration in anticipation of slow-onset environmental or climate change impacts is more likely to be regarded as voluntary. Complementary protection has therefore been argued to be inadequate for addressing the complexities of environmentally related migration (McAdam, 2012).

\section{New international instrument}

A number of models for a new international instrument have also been proposed, including a stand-alone convention, a protocol to the United Nations Framework Convention on Climate Change (UNFCCC) and regional agreements under an international framework agreement (Biermann \& Boas, 2010; Docherty \& Giannini, 2009; Hodgkinson, Burton, Anderson, \& Young, 2010). These proposals have significant variations in approach and detail (Appave, 2012), reflecting the difficulties involved in conceptualising environmentally related migration. There has been no common agreement among the proposals on how to define the individuals (and groups) their instruments seek to protect, including in relation to use of the term 'refugee'. Nor has there been a common approach to the applicability of the proposed instruments in relation to forced and/or voluntary movement, internal and/or cross-border movement, and rapid-onset and/or slow-onset environmental events 
(including how the interaction between environmental events and climate change is understood and whether climate change factors should be the specific focus).

Kälin and Schrepfer (2012) have argued that, in the present context, negotiating such an instrument is likely to be difficult because of the 'largely incompatible interests of potential countries of origin and countries of destination' (p. 70). Further, if not appropriately targeted, McAdam and Saul (2010) have suggested that a new instrument could actually 'encourage general migration, abusive claims and people smuggling'.

\section{Guiding Principles on Internal Displacement}

People displaced internally have been argued to be better protected by international norms (including human rights) than those who move internationally, as exemplified by governments having widely adopted the nonbinding Guiding Principles on Internal Displacement (Appave, 2012; Koser, 2011; Leighton, 2010). It has been argued that policymakers could usefully apply the Guiding Principles to situations of environmentallyrelated migration across borders. The Guiding Principles include in their scope 'persons or groups of persons who have been forced or obliged to flee or leave their homes or places of habitual residence, in particular as a result of or in order to avoid the effects of ... natural or human-made disasters' (United Nations Commission on Human Rights, 1998).

However, the requirement that people are forced or obliged to move creates a lack of clarity once more about whether slow-onset processes are covered (Zetter, 2010), particularly as economic motivations for movement, which can be related to the impacts of climate change on livelihood and economic opportunities, were deliberately excluded from the text (Koser, 2011). Further, as the Guiding Principles are nonbinding, if they are not implemented effectively in national laws and policies they may not provide any actual guarantees to displaced people (Koser, 2011).

\section{Regional responses}

In view of the range of scenarios in which environmentally related migration may occur, McAdam (2011) has argued that localised or regional approaches may provide better responses than generic international normative frameworks. Regional discussions may provide an avenue for policymakers to consider the different contexts in which environmentally- 
related migration may pose challenges and opportunities. For example, the specific nature of the threat posed to low-lying Pacific Island nations by rising sea levels and the priorities of affected populations have been prominent features of Pacific regional discussions for a number of years. Importantly, the Pacific Islands Forum developed and endorsed the Niue Declaration on Climate Change in 2008 (Pacific Islands Forum Secretariat, 2008). On a more practical level, affected states in the Pacific are taking action on possible scenarios ranging from internal displacement to nonviability. For example, a recent decision by Kiribati to purchase an island in Fiji, while officially described as a response to food security, has been interpreted by some commentators in terms of environmentallyrelated migration.

Also in a regional context, McAdam (2012) has discussed the potential utility of existing regional instruments, such as the Organization of African Unity Convention Governing the Specific Aspects of Refugee Problems in Africa and the Cartagena Declaration on Refugees in Latin America. Both define refugees more broadly than the Refugee Convention, and include people who have moved because of events that have disturbed public order. McAdam (2012) has argued that under both instruments it is likely that attributing movement to 'climate change' would be difficult, and that protection seems to be limited to people who have already moved in response to an actual threat, therefore limiting coverage of people moving in anticipation of future environmental impacts.

While the European Union (EU) is a supranational body, with a different character from other regional bodies, it is relevant here to note the EU Temporary Protection Directive, which establishes temporary protection in cases of 'mass influx' of displaced persons. The Directive does not mention environmental factors explicitly, but the open definition of 'mass influx' is argued to provide flexibility (EC, 2013). However, invoking the Directive would require agreement by a majority of EU member states and it is considered unlikely that it would cover environmental migrants travelling as a result of slow-onset processes (Koser, 2012). Nonetheless, acknowledging that environmentally related migration may pose increasing challenges in the future, the EC has published a working document, Climate change, environmental degradation, and migration, which provides an overview of the EU perspective on the complexities involved in addressing the issues, and outlines the need for increased knowledge, dialogue and cooperation in order to build policy (EC, 2013). 


\section{National-level policy settings}

Several countries have developed domestic laws and policies on environmentally related migration, although this has been limited and the implementation of such policies is, in some cases, untested.

Complementary forms of protection for people unable to return to their country of origin are provided for in Sweden's Aliens Act ('because of an environmental disaster') ${ }^{2}$ and Finland's Aliens Act ('as a result of an environmental catastrophe'). ${ }^{3}$ Finland's Act also provides for temporary protection where 'there has been a massive displacement of people ... as a result of an armed conflict, some other violent situation or an environmental disaster'. ${ }^{4}$ As none of these provisions has yet been tested, their operation is unclear.

In the US, legislation allows for Temporary Protected Status (TPS) to be granted to people who are 'temporarily unable to return to their home country because of ... an environmental disaster' (Martin, 2010, p. 3). TPS only applies to people already in the US at the time of a disaster (not to those fleeing an event), and the designation of nationals to whom it applies is discretionary (Koser, 2012; Martin, 2010).

A summary of national-level policy responses is in Table 12.1.

Table 12.1: Overview: National-level policies relevant to environmentally related migration

\begin{tabular}{|l|l|l|}
\hline Country & Response & Comments \\
\hline Finland & $\begin{array}{l}\text { Aliens Act provides for } \\
\text { complementary protection } \\
\text { for people unable to return } \\
\text { to their country of origin 'as } \\
\text { a result of an environmental } \\
\text { catastrophe'.1 }\end{array}$ & $\begin{array}{l}\text { As these provisions have not yet } \\
\text { been tested, their operation is } \\
\text { Aliens Act provides for } \\
\text { temporary protection where } \\
\text { 'there has been a massive } \\
\text { displacement of people ... as } \\
\text { a result of an armed conflict, } \\
\text { some other violent situation or } \\
\text { an environmental disaster'. }\end{array}$ \\
\hline
\end{tabular}

Aliens Act (2005:716) [Sweden], Chapter 4, Section 2.

Aliens Act (301/2004, amendments up to 458/2009 included) [Finland], Section 88a(1).

Aliens Act (301/2004, amendments up to 458/2009 included) [Finland], Section 109. 


\begin{tabular}{|l|l|l|}
\hline Country & Response & Comments \\
\hline Sweden & $\begin{array}{l}\text { Aliens Act provides for } \\
\text { complementary protection for } \\
\text { people unable to return to their } \\
\text { country of origin 'because of } \\
\text { an environmental disaster'. }\end{array}$ & $\begin{array}{l}\text { As this provision has not yet been } \\
\text { tested, its operation is unclear. }\end{array}$ \\
\hline US & $\begin{array}{l}\text { Legislation allows for } \\
\text { Temporary Protected Status } \\
\text { (TPS) to be granted to people } \\
\text { who are 'temporarily unable } \\
\text { to return to their home } \\
\text { country because of ... an } \\
\text { environmental disaster'. }\end{array}$ & $\begin{array}{l}\text { TPS only applies to people already } \\
\text { in the US at the time of a disaster } \\
\text { (not to those fleeing an event). } \\
\text { The designation of nationals to } \\
\text { whom TPS applies is discretionary. }\end{array}$ \\
\hline Australia & $\begin{array}{l}\text { Seasonal Worker Program } \\
\text { (SWP) introduced in 2012 } \\
\text { allows Australian businesses } \\
\text { to recruit workers from Pacific } \\
\text { states. }\end{array}$ & $\begin{array}{l}\text { The SWP is designed to meet } \\
\text { Australian workforce needs and } \\
\text { contribute to poverty reduction and } \\
\text { economic development in Pacific } \\
\text { countries. It is not designed to } \\
\text { address climate change adaptation. }\end{array}$ \\
\hline New Zealand & $\begin{array}{l}\text { Pacific Access Category (PAC) } \\
\text { allows a number of Pacific } \\
\text { Islanders to immigrate to New } \\
\text { Zealand each year. }\end{array}$ & $\begin{array}{l}\text { The PAC is based on employment- } \\
\text { it is not designed to address climate } \\
\text { change adaptation. }\end{array}$ \\
\hline $\begin{array}{l}\text { chemporary Protection Directive } \\
\text { establishes temporary } \\
\text { protection in cases of 'mass } \\
\text { influx' of displaced persons. }\end{array}$ & $\begin{array}{l}\text { The Directive does not mention } \\
\text { environmental factors explicitly, but } \\
\text { the open definition of 'mass influx' is } \\
\text { argued to provide flexibility. } \\
\text { Invoking the Directive would require } \\
\text { agreement by a majority of EU } \\
\text { member states. } \\
\text { It has been considered unlikely that } \\
\text { the Directive would cover migrants } \\
\text { travelling as a result of slow-onset } \\
\text { environmental processes. }\end{array}$ \\
\hline EU \\
(supranational)
\end{tabular}

Source: (1) Finland, Aliens Act (301/2004, amendments up to 458/2009 included), Section 88a; (2) Finland, Aliens Act (301/2004, amendments up to 458/2009 included), Section 109; (3) Sweden, Aliens Act (2005:716), Chapter 4, Section 2; (4) Quoted in Martin (2010), p. 3; (5) Koser (2012), p. 10; (6) Martin (2010), p. 3; (7) EC (2013), p. 19; (8) Koser (2012), p. 10.

In the Australian context, there have been a number of instances in which migration-related operational responses have been put into effect following sudden-onset environmental disasters (e.g. the 2004 Indian Ocean tsunami), similar to the US's TPS policy approach. While Australia's responses have not been formalised via legislation, a similar approach is able to be applied, allowing people in Australia to remain following natural disasters on a case-by-case basis. 
In Australia, an attempt to directly address the issue of 'climate refugees' came in the form of the Migration (Climate Refugees) Amendment Bill, introduced by the Greens in 2007. The Bill sought to amend the Migration Act to include a 'climate change refugee' visa class for 'a person who has been displaced as a result of a climate change induced environmental disaster'. ${ }^{5}$ This approach raised the difficulties involved in identifying an environmental event as being induced by climate change, which the Bill proposed to make the subject of a determination by the Minister for Immigration. Questions were also raised about the implications for both Australia's security and humanitarian priorities, particularly whether the new visa category would attract migrants from around the world (which could include irregular migrants), and whether it would impact on Australia's humanitarian resettlement quota (Koser, 2012). The Bill did not proceed to a vote and lapsed.

\section{Utilising existing policies}

Some commentators on environmentally related migration have argued that 'there are actually a number of existing policy fields that can be relied upon to address the challenges it raises, including development strategy, humanitarian affairs, post-disaster interventions, or immigration and admission policies' (Piguet et al., 2011, p. 24). Each of these policy fields covers particular issues relevant to different stages of environmentallyrelated migration, but in light of the complexities that characterise the phenomenon, Warner (2010) has argued that institutional and policy 'silos' limit the effectiveness of existing responses. Warner has cited existing governance gaps in the protection of environmental migrants who are unable to return after rapid-onset disasters, and those whose movement is related to slow-onset processes.

To address these gaps, many commentators have highlighted the need for a stronger evidence-base, policy dialogue and collaboration between institutions and practitioners in different policy fields in order to understand environmental and climate change impacts on livelihoods and migration (Boano et al., 2008; Findlay \& Geddes, 2011; Warner, 2010).

5 Australia, Migration (Climate Refugees) Amendment Bill 2007 (Cth), Schedule 1, Clause 2(2). 
Due to their key relevance in this context, approaches to adaptation and migration have regularly been discussed in these arguments. Notwithstanding White's arguments about the potentially contentious nature of adaptation (White, 2011), commentators have suggested that not only can adaptation function as a way to reduce migration, but that migration can also function as an adaptation strategy that may significantly increase the resilience of communities to anticipated climate change impacts.

Discussion of migration and adaptation has often turned to the impact of sea-level rise on Pacific Island nations, as a part of the world in which 'long-term migration might be the only response for some communities vulnerable to climate change' (Elliott, 2010, p. 184).

Australia's humanitarian aid and development programs include a significant focus on the Pacific, including a number of projects aimed at building the resilience of communities and reducing disaster risk. However, its humanitarian action does not specifically address crossborder displacement due to natural disasters. From the migration policy side, migration from some Pacific Islands to Australia is long term and well established. In this context, Australia introduced a Seasonal Worker Program in 2012, which allows Australian businesses to recruit workers from Pacific states to both meet Australian workforce needs in particular sectors and to contribute to poverty reduction and economic development in Pacific countries. This program is not designed to address climate change adaptation, and has not been implemented in such terms. Similarly, New Zealand has introduced a Pacific Access Category which allows a number of Pacific Islanders to immigrate to New Zealand each year based on employment, not on climate change adaptation (Martin, 2010). These examples illustrate the potential utility of existing policies that could be adjusted to accommodate emerging priorities, and could be expanded, for example, in response to different issues, and possibly involve utilising migration as an adaptation strategy.

Finally, it is important to note that arguments for the utilisation of existing policies to address environmental and climate change migration should not be taken as rejecting the development of new normative legal and policy instruments outright. Rather, drawing on the conceptual challenges that the environment-migration nexus presents for the development of these instruments, it is argued that an absence of consensus on the desirability 
of such new standards does not imply that nothing can be done (Piguet et al., 2011; McAdam, 2010). How sustainable such existing policy settings are, in relation to future migration, is a key question.

\section{Conclusions}

A fundamental challenge for policymakers and decision-makers attempting to respond to environmentally related migration is the difficulty involved in conceptualising and defining the links between environmental and climate change factors and international migration, including irregular migration. Further, the lack of reliable empirical research and analysis on the issues means there is a weak evidence-base to underscore effective policy development or implementation.

Building the research base to determine the role of environmental factors among the range of other drivers that contribute to decision-making processes involved in regular and irregular migration across borders is complicated. Effective policy responses need to take into account the nature of particular environmental events or climate impacts, as well as the local social, political and economic contexts in which they occur.

Some authors have proposed that a range of existing national policies can be utilised to address the challenges raised by environmental migration. Given the multilayered nature of environmentally related migration, cooperation and coordination between different policy areas has been widely recommended to ensure that overlapping issues are captured.

A number of approaches to managing environmentally related migration have been put forward at both the international and national levels. However, all of these approaches have struggled to comprehensively address the multifaceted nature of the issues involved. One of the greatest challenges ahead will be to understand the nature of environmentallyrelated migration in order to develop policy responses that will effectively address potential future movement across borders. 


\section{Reference list}

A question of climate refugees. Editorial. (2011). New Scientist, 2180. Retrieved from www.newscientist.com/article/mg21028103-600-aquestion-of-climate-refugees/.

Appave, G. (2012). Emerging legal issues in international migration. In Opeskin, B., Perruchoud, R., \& Redpath-Cross, J. (Eds), Foundations of international migration law (pp. 390-418). Cambridge: Cambridge University Press. doi.org/10.1017/CBO9781139084598.016

Bates, D. (2002). Envrionmental refugees? Classifying human migration caused by environmental change. Population and Environment, 23(5), 465-77. doi.org/10.1023/A:1015186001919

Bierman, F., \& Boas, I. (2010). Preparing for a warmer world: Towards a global governance system to protect climate change refugees. Global Environmental Politics, 10(1), 60-88. doi.org/10.1162/glep. 2010.10.1.60

Black, R. (2001). Environmental refugees: Myth or reality? New Issues in Refugee Research, working paper no. 34. Sussex: United Kingdom.

Boano, C., Zetter, R., \& Morris, T. (2008). Environmentally displaced people: Understanding the linkages between environmental change, livelihoods and forced migration. Oxford: Refugee Studies Centre, University of Oxford.

Brown, O. (2008). Migration and climate change. Geneva: International Organisation for Migration.

Castles, S. (2002). Environmental change and forced migration: Making sense of the debate. Geneva: UNHCR Evaluation and Policy Analysis Unit.

Castles, S. (2011). Concluding remarks on the climate change-migration nexus. In Piguet, E., Pécoud, A., \& de Guchteneire, P. (Eds), Migration and climate change (pp. 415-27). Cambridge: Cambridge University Press.

Christian Aid. (2007). Human tide: The real migration crisis. London: Author. 
Collinson, S. (2010). Developing adequate humanitarian responses. Washington DC: German Marshall Fund.

Crisp, J. (1999). Who has counted the refugees?: UNHCR and the politics of numbers. New Issues in Refugee Research, working paper, no. 12. Geneva: United Nations High Commissioner for Refugees.

Docherty, B., \& Giannini, T. (2009). Confronting a rising tide: A proposal for a convention on climate change refugees. Harvard Environmental Law Review, 33(2), 349-403.

Dun, O., \& Gemenne, F. (2008). Defining environmental migration: Why it matters so much, why it is controversial and some practical processes which may help to move forward. Revue Asylon, 6. Retrieved from www.reseau-terra.eu/article847.html.

El-Hinnawi, E. (1985). Environmental refugees. Nairobi: United Nations Environment Program.

Elliott, L. (2010). Climate migration and climate migrants: What threat, whose security? In McAdam, J. (Ed.), Climate change and displacement: Multidisciplinary perspectives (pp. 175-90). Oxford: Hart Publishing.

European Commission. (2013). Commission staff working document: Climate change, environmental degradation, and migration. Working paper. Brussels: Author.

Findlay, A., \& Geddes, A. (2011). Critical views on the relationship between climate change and migration: Some insights from the experience of Bangladesh. In Piguet, E., Pécoud, A., \& de Guchteneire, P. (Eds), Migration and climate change (pp. 138-59). Cambridge: UNESCO Publishing, Cambridge University Press.

Geddes, A., \& Somerville, W. (2013). Migration and environmental change: Assessing the developing European approach. Migration Policy Institute, Europe policy brief series, no. 2. Brussels: Migration Policy Institute.

Gemenne, F. (2011). How they became the human face of climate change: Research and policy interactions in the birth of the 'environmental migration' concept. In Piguet, E., Pécoud, A., \& de Guchteneire, P. (Eds), Migration and climate change (pp. 225-59). Cambridge: UNESCO Publishing, Cambridge University Press. 
Hodgkinson, D., Burton, T., Anderson, H., \& Young, L. (2010). The hour when the ship comes in: A convention for persons displaced by climate change. Monash University Law Review, 36(1), 69-119.

Hugo, G. (1996). Environmental concerns and international migration. International Migration Review, 30(1), 105-31. doi.org/ $10.2307 / 2547462$

Hugo, G. (2010). Climate change-induced mobility and the existing migration regime in Asia and the Pacific. In McAdam, J. (Ed.), Climate change and displacement: Multidisciplinary perspectives (pp. 9-36). Oxford: Hart Publishing.

International Organisation for Migration. (2013). Towards the 2013 highlevel dialogue on international migration and development: Final report of the high-level dialogue series. Geneva: Author.

Jacobson, J. (1988). Environmental refugees: A yardstick of habitability. Worldwatch institute paper, no. 86. Washington, DC: Worldwatch Institute.

Kälin, W., \& Schrepfer, N. (2012). Protecting people crossing borders in the context of climate change: Normative gaps and possible approaches. Geneva: Office of the United Nations High Commissioner for Refugees.

Kibreab, G. (1997). Environmental causes and impact of refugee movements: A critique of the current debate. Disasters, 21(1), 20-38. doi.org/10.1111/1467-7717.00042

Kirsch-Wood, J., Korrebord, J., \& Linde, A.-M. (2008). What humanitarians need to do. Forced Migration Review, 31, 40-41.

Kniveton, D., Schmidt-Verkerk, K., Smith, C., \& Black, R. (2008). Climate change and migration: Improving methodologies to estimate flows. Geneva: International Organization for Migration.

Koser, K. (1996). Changing agendas in the study of forced migration: A report on the fifth international research and advisory panel. Journal of Refugee Studies, 9(4), 353-66. doi.org/10.1093/jrs/9.4.353 
Koser, K. (2011). Climate change and internal displacement: Challenges to the normative framework. In Piguet, E., Pécoud, A., \& de Guchteneire, P. (Eds), Migration and climate change (pp. 289-305). Cambridge: UNESCO Publishing, Cambridge University Press.

Koser, K. (2012). Environmental change and migration: Implications for Australia. Sydney: Lowy Institute for International Policy.

Koser, K. (2013). Who cares when migrants become internally displaced persons? Retrieved from Brookings Institute: www.brookings.edu/ blog/up-front/2013/10/08/who-cares-when-migrants-becomeinternally-displaced-persons/.

Leighton, M. (2010). Climate change and migration: Key issues for legal protection of migrants and displaced persons. Washington DC: German Marshall Fund.

Leighton, M. (2011). Drought, desertification and migration: Past experiences, predicted impacts and human rights issues. In Piguet, E., Pécoud, A., \& de Guchteneire, P. (Eds), Migration and climate change (pp. 331-58). Cambridge: UNESCO Publishing, Cambridge University Press.

Lonergan, S. (1998). The role of environmental degradation in population displacement. Environmental change and human security project report no. 4. Victoria, Canada: University of Victoria.

Martin, S. (2010). Climate change and international migration. Washington DC: German Marshall Fund.

McAdam, J. (2011, 29-30 March). Climate change, displacement and the role of international law and policy. Paper presented at the international dialogue on migration 2011: The future of migration: Building capacities for change, Geneva.

McAdam, J. (2012). Climate change, forced migration and international law. Oxford: Oxford University Press. doi.org/10.1093/acprof:oso/ 9780199587087.001 .0001

McAdam, J., \& Saul, B. (2010). Displacement with dignity: International law and policy responses to climate change migration and security in Bangladesh. University of New South Wales Faculty of Law research series, no. 63. Berkeley: Bepress. 
McGregor, J. (1993). Refugees and the environment. In Black, R., \& Robinson, V. (Eds), Geography and refugees: Patterns and processes of change (pp. 157-70). London: Belhaven.

Morrissey, J. (2009). Environmental change and forced migration: A state of the art review. Oxford: Refugee Studies Centre, University of Oxford.

Morrissey, J. (2012). Rethinking the 'debate on environmental refugees': From maximilists and minimalists to proponents and critics. Journal of Political Ecology, 19, 36-49. Retrieved from jpe.library.arizona.edu/ volume_19/Morrissey.pdf.

Myers, N. (1993). Environmental refugees in a globally warming world: Estimating scope of what could well be a prominent international phenomenon. Bio Science, 43(11), 752-61. doi.org/10.2307/1312319

Myers, N. (1997). Environmental refugees. Population and Environment, 18(5), 509-24.

Myers, N. (2001). Environmental refugees: Our latest understanding. Philosophical Transactions of the Royal Society B, 356, 16.1-16.5.

Myers, N. (2005). Environmental refugees: An emergent security issue. Paper presented at the thireteenth economic forum, Prague.

Myers, N., \& Kent, J. (1995). Environmental exodus: An emergent crisis in the global arena. Washington DC: The Climate Institute.

Newland, K. (2011). Climate change \& migration dynamics. Washington DC: Migration Policy Institute \& European University Institute.

Pacific Islands Forum Secretariat. (2008). Pacific Island forum leaders endorse the Niue declaration on climate change. Press statement retrieved from www.spc.int/ppapd/index.php?option=com_content\& task=view\&id $=131$.

Piguet, E. (2011). The migration/climate change nexus: An assessment. Paper presented at the international conference on rethinking migration: climate, resource conflicts and politics of migration/ refugees in Europe, Berlin.

Piguet, E., Pécoud, A., \& de Guchteneire, P. (2011). Introduction: Migration and climate change. In Piguet, E., Pécoud, A., \& de Guchteneire, P. (Eds), Migration and climate change (pp. 1-33). Cambridge: UNESCO Publishing, Cambridge University Press. 
Suhrke, A. (1992). Environmental degradation, migration and conflict. Paper presented at the Brookings Institute, Washington DC.

Suhrke, A. (1993). Pressure points: Environmental degredation, migration and conflict, Cambridge: American Academy of Art and Science.

Transatlantic study team on climate-induced migration. (2010). Climate change and migration: Report of the transatlanticstudy team. Washington DC: German Marshall Fund.

United Nations High Commissioner for Refugees. (1993). The state of the world's refugees 1993: The challenge of protection. Geneva: Author.

United Nations High Commissioner for Refugees. (2009). Climate change, natural disasters and human displacement: A UNHCR perspective. Geneva: Author.

Warner, K. (2010). Assessing institutional and governance needs related to environmental change and human migration. Washington DC: German Marshall Fund.

White, G. (2011). Climate change and migration: Security and borders in a warming world. Oxford: Oxford University Press. doi.org/10.1093/ acprof:oso/9780199794829.001.0001

Zetter, R. (2007). More labels, fewer refugees: Remaking the refugee label in an era of globalization. Journal of Refugee Studies, 20(2), 172-92.

Zetter, R. (2010). Protecting people displaced by climate change: Some conceptual challenges. In McAdam, J. (Ed.), Climate change and displacement: Multidisciplinary perspectives (pp. 131-50). Oxford: Hart Publishing.

\section{Legislative documents}

Australia, Migration (Climate Refugees) Amendment Bill 2007 sch 1, cl 2(2).

Finland, Aliens Act (301/2004, amendments up to 458/2009 included), 30 April 2004. Retrieved from www.refworld.org/docid/ 4b4d93ad2.html.

Sweden, Aliens Act (2005:716), 31 March 2006. Retrieved from www. refworld.org/docid/3ae6b50a1c.html. 
United Nations Commission on Human Rights. (1998). Report of the representative of the Secretary-General, Mr. Francis M. Deng, submitted pursuant to commission resolution 1997/39. Addendum: Guiding principles on internal displacement. Retrieved from www.refworld.org/ docid/3d4f95e11.html.

United Nations General Assembly, International Covenant on Civil and Political Rights, 16 December 1966, United Nations, Treaty Series, vol. 999, p. 171. Retrieved from www.refworld.org/docid/ 3ae6b3aa0.html. 
This text is taken from A Long Way to Go: Irregular Migration Patterns, Processes, Drivers and Decision-making, edited by Marie McAuliffe and Khalid Koser, published 2017 by ANU Press, The Australian National University, Canberra, Australia.

dx.doi.org/10.22459/LWG.12.2017.12 